\title{
SISTEM INFORMASI PELETAKAN BERKAS REKAM MEDIK PADA KLINIK ROSMAWATI
}

\author{
Salma Nur Jihan \\ Universitas Indraprasta PGRI \\ Jl. Raya Tengah No. 80, Kel. Gedong, Kec. Pasar Rebo, Jakarta Timur \\ sanjijihan22@gmail.com
}

\begin{abstract}
ABSTRAK
Pada klinik Rosmawati dalam pelaksaan peletakan berkas rekam medik pendataan masih menggunakan Microsoft Excel yang tidak mendukung fasilitas database sehingga dalam pencarian data memakan waktu relatif lama. Pembuatan Laporan menggunakan Microsoft Word, apabila akan mencetak laporan, pengguna terlebih dahulu membuka laporan data yang telah dibuat di Microsoft Excel dan menyalin dokumen tersebut ke dalam Microsoft Word sehingga menyebabkan terjadinya keterlambatan pelaporan. Adanya berkas hilang saat akan digunakan dan banyaknya berkas dalam rak yang sulit ditemukan sehingga pelayanan pasien terganggu dan waktu tunggu pasien menjadi lebih lama. Hal ini akan berpengaruh kepada mutu pelayanan yang kurang efektif dan efisien. Berdasarkan hal tersebut penulis melihat pentingnya sebuah aplikasi sistem informasi peletakan yang menunjang semua kebutuhan agar semua data penyimpanan berkas tersistem dengan baik dan tercapainya mutu pelayanan. Penelitian ini bertujuan untuk mengetahui sistem yang sedang berjalan, membuat perancangan sistem, melakukan analisis pengujian sistem serta melakukan implementasi sistem peletakan berkas rekam medik. Metode Pengembangan Sistem menggunakan metode waterfall. Metodologi penelitian dalam sistem pengolahan data yaitu pengumpulan data seperti wawancara, observasi, studi dokumentasi, melakukan penelitian kepustakaan yang relevan dengan masalah sistem informasi. Hasil dari penelitian diperoleh bahwa dengan diterapkannya sistem ini maka dapat menunjang mutu pelayanan terutama dalam pencarian berkas rekam medik dan pelaporannya.
\end{abstract}

Kata Kunci: Sistem Informasi, Peletakan Berkas, Rekam Medik

\section{ABSTRACT}

At the Rosmawati clinic, in the implementation of placing medical record files, data collection still uses Microsoft Excel which does not support database facilities so that searching for data takes a relatively long time. Report generation using Microsoft Word, when the user is going to print the report, the user first opens the data report that has been created in Microsoft Excel and copies the document into Microsoft Word, causing delays in reporting. There are missing files when they are going to be used and the number of files in the shelves are difficult to find so that patient service is disrupted and patient waiting time becomes longer. This will affect the quality of service that is less effective and efficient. Based on this, the author sees the importance of an application of a laying information system that supports all the needs so that all data file storage is properly systemized and the achievement of service quality is achieved. This study aims to determine the current system, make system design, analyze system testing and implement the medical record file placement system. System Development Method using the waterfall method. The research methodology in the data processing system is collecting data such as interviews, observations, documentation studies, conducting library research that is relevant to information systems problems. The results of the study showed that with the implementation of this system, it can support the quality of service, especially in the search for medical record files and reporting.

Key Word: Information Systems, File Placement, Medical Record.

\section{PENDAHULUAN}

Di era globalisasi ini, setiap instansi membutuhkan informasi yang cepat dan akurat. Salah satu informasi yang dibutuhkan ialah informasi penyimpanan berkas yang dimiliki oleh suatu instansi. Klinik Rosmawati adalah instansi swasta yang bergerak di bidang pelayanan kesehatan khususnya untuk kota
Bekasi. Proses penyimpanan suatu berkas memegang peranan yang sangat penting dalam efektifitas kegiatan suatu perusahaan atau suatu organisasi yaitu merupakan sumber informasi dan juga referensi bagi suatu perusahaan atau organisasi. Mengingat pentingnya proses penyimpanan ini pemerintah Indonesia bahkan membuat peraturan dan perundangan yang 305 | Sistem Informasi Peletakan Berkas Rekam Medik pada Klinik Rosmawati 
mengatur tentang kearsipan nasional. Adapun untuk tujuan dari penyimpanan suatu berkas sendiri adalah agar berkas dapat disimpan dan ditemukan kembali dengan cepat dan tepat (Dwihartanti 2014). Untuk menunjang suatu tujuan ini pasti dibutuhkan tata cara tertentu seperti menggunakan map arsip dengan cara disusun mendatar, menyekat bagian berkas per berkas menggunakan sekat petunjuk dengan cara berkas disusun tegak lurus, menyimpan berkas di sebuah lemari atau rak arsip juga bisa dilakukan dengan cara disusun tegak lurus. Masing-masing tata cara tersebut dapat disempurnakan dengan dilakukannya metode-metode sistem penyusunan. Pertama sistem penyusunan bedasarkan abjad, yaitu berkas disusun bedasarkan abjad dari masing-masing nama berkas. Kedua, sistem penyusunan tanggal, yaitu berkas disusun dengan menggunakan tanggal berkas tersebut dibuat, namun untuk sistem ini kurang direkomendasikan karena rentan terjadi kesalahan. Ketiga, menggunakan sistem penomoran, sistem ini bekerja dengan cara setiap berkas atau arsip yang akan disimpan akan melalui proses penomoran terlebih dahulu lalu diurutkan dari angka terkecil sampai yang terbesar.

Arsip dalam bahasa yunani yaitu "Arsip berasal dari kata arche, kemudian berubah menjadi archea, berubah kembali menjadi archeon. Archea artinya dokumen atau catatan mengenai permasalahan" (Sugiarto dan Wahyono 2015). Arsip dalam bahasa belanda dikenal dengan archief, di inggris dikenal dengan istilah archives dan amerika dikenal dengan record dan archives". Kata-kata istilah itu memiliki arti yaitu catatan tertulis yang disimpan (Muhidin dan Winata 2016). Arsip dalam bahasa Indonesia adalah "warkat" yang pada pokoknya memiliki pengertian bahwa "setiap catatan tertulis baik dalam bentuk gambar atau pun bagan yang memuat keterangan-keterangan suatu subyek (pokok persoalan) atau pun peristiwa-peristiwa yang dibuat oleh orang untuk membantu daya ingat orang (itu) pula" (Barthos 2016). Penjelasan diatas dapat bermakna bahwa kearsipan merupakan suatu proses mulai dari penciptaan, penerimaan, pengumpulan, pengaturan, pengendalian, pemeliharaan dan perawatan serta penyimpanan dokumen menurut sistem tertentu yang saat dibutuhkan dapat ditemukan dengan cepat dan tepat ditemukan.
Pada klinik Rosmawati dalam pelaksaan peletakan berkas rekam medik pendataan masih menggunakan Microsoft Excel. Microsoft Excel tidak mendukung fasilitas database sehingga dalam pencarian data peletakan berkas rekam medik memakan waktu yang relatif lama karena datanya yang terpisah menurut hari, bulan dan tahun. Pembuatan Laporan yang ada saat ini menggunakan Microsoft Word, sehingga apabila akan mencetak laporan tersebut, maka pengguna terlebih dahulu membuka laporan data peletakan berkas rekam medik yang telah dibuat di Microsoft Excel dan menyalin dokumen tersebut ke dalam Microsoft Word.

Hal ini menyebabkan terjadinya keterlambatan pelaporan. Adanya berkas-berkas yang hilang sehingga saat akan dipakai untuk kebutuhan pasien berkas tersebut tidak ada, lalu banyaknya berkas-berkas yang sudah disimpan dalam rak namun sulit ditemukan saat akan digunakan oleh dokter, sehingga pelayanan pasien terganggu, dan waktu tunggu pasien menjadi lebih lama. Hal ini akan berpengaruh kepada mutu pelayanan yang kurang efektif dan efisien.

Berdasarkan hal tersebut penulis melihat betapa pentingnya sebuah aplikasi sistem informasi peletakan berkas rekam medik yang menunjang semua kebutuhan pegawai agar semua data penyimpanan berkas rekam medik dapat tersistem dengan baik dan dapat tercapainya mutu pelayanan. Sehingga penulis tertarik untuk memilih judul "Sistem Informasi Peletakan Berkas Rekam Medik Pada Klinik Rosmawati”.

\section{METODE PENELITIAN}

Metodologi penelitian yang digunakan dalam sistem pengolahan data yaitu teknik pengumpulan data seperti wawancara, observasi, studi dokumentasi, serta melakukan penelitian kepustakaan yang relevan dengan masalah sistemsistem informasi. Metode Pengembangan Sistem yang digunakan menggunakan metode waterfall. Menurut (Sugiyono 2016), "Metode penelitian dan pengembangan atau dalam inggrisnya Research and Development adalah metode penelitian yang digunakan untuk menghasilkan produk tertentu, dan menguji keefektifan produk tersebut". Dan untuk metode penelitian yang digunakan untuk penyajian data penelitian ini merupakan metode penelitian 
kualitatif, yang bertujuan untuk mencari, menganalisis dan mengelola dari peristiwa langsung di lapangan dengan memahami interaksi sosial dengan wawancara dan observasi. Menurut (Sugiyono 2018) metode penelitian kualitatif adalah metode penelitian yang berlandaskan pada filsafat, yang digunakan untuk meneliti pada kondisi ilmiah (eksperimen) dimana peneliti sebagai instrumen, teknik pengumpulan data dan di analisis yang bersifat kualitatif lebih menekankan pada makna. Metodelogi penelitian kualitatif bertujuan untuk menganalisis dan mendeskripsikan fenomena atau obyek penelitian melalui aktivitas sosial, sikap dan persepsi orang secara individu atau kelompok.

\section{Desain Penelitian}

Desain penelitian adalah semua proses yang diperlukan dalam perencanaan dan pelaksanaan penelitian (Nazir 2014). Desain penelitian merupakan pedoman dalam melakukan proses penelitian diantaranya dalam menentukan instrumen pengambilan data, pengumpulan data serta analisa data. Dengan pemilihan desain penelitian yang tepat dihrapkan akan dapat menbantu peneliti dalam menjalankan penelitian secara benar. Tanpa desain yang benar seorang peneliti tidak akan dapat melakukan penelitian dengan baik karena tidak memiliki pedoman penelitian yang jelas. Metode penelitian menjelaskan desain penelitian, rancangan kegiatan ruang lingkup atau objek penelitian, tempat penelitian, dan teknik penelitian.

\section{Metode Pegumpulan Data}

Pengumpulan data dalam penelitian ilmiah ialah prosedur sistematis untuk memperoleh data yang diperlukan (Satori dan Komariah 2017). Dalam pengumpulan data, terdapat dua jenis data pokok yang perlu dikumpulkan, yaitu data primer dan data sekunder. Dalam metode pengumpulan data, yang merupakan data primer adalah hasil dari observasi dan wawancara terhadap narasumber yang berkaitan dengan pokok penelitian. Data lainnya yaitu data sekunder didapatkan melalui metode pengumpulan data.

\section{Observasi (Pengamatan)}

Observasi merupakan salah satu cara mengumpulkan data yang diperlukan dengan cara melakukan pengamatan dan meneliti secara langsung gejala atau peristiwa yang diselidiki oleh peneliti. Peneliti melakukan observasi mengenai sistem aplikasi peletakan

berkas rekam medik, dan pembuatan laporanlaporan akhir tahun. Pengamatan ini dilaksanakan pada awal bulan Maret 2021 sampai dengan bulan Juni 2021. Metode ini diperlukan untuk mengetahui atau mendapatkan data yang masih belum lengkap yang tidak didapat dengan melalui metode wawancara.

\section{Wawancara}

Wawancara merupakan proses memperoleh keterangan untuk tujuan penelitian dengan cara melakukan Tanya jawab kepada responden ataupun pihak-pihak yang terkait, dengan mengajukan beberapa pertanyaan yang ada kaitannya dengan kebutuhan data yang dikumpulkan oleh peneliti.

Wawancara dilakukan dengan dr. Rosmawati Ritonga selaku Pemilik dari Klinik Rosmawati, beliau menyatakan bahwa permasalahan dalam pendataan pembayaran dan data-data pengelolaan lainnya yang terkait dengan sistem aplikasi peletakan berkas rekam medik saat ini masih belum terkelola dengan efektif, penggunaan sistem yang seadanya membuat beberapa kali terjadi kesalahan. Selain itu pembuatan laporan data-data peletakan berkas rekam medik juga masih membutuhkan waktu yang cukup lama dan tingkat ketelitian yang tinggi, dikarenakan harus mengumpulkan data-data yang ada yang masih berupa lembaran-lembaran berkas. Cara yang masih dilakukan ini perlu dirubah menjadi terkomputerisasi dan dibuatkan sistem aplikasi untuk mengolah data-data yang berhubungan dengan pendataan peletakan berkas rekam medik supaya lebih efektif. Dengan hasil pengolahan data yang efektif diharapkan informasi yang disajikan lebih akurat dan memudahkan bagi pihak instansi yang bertugas.

\section{Studi Pustaka}

Untuk memperoleh data sekunder, peneliti menggunakan teknik pengumpulan data dengan cara satu dipustaka yaitu, mengumpulkan datadata yang sudah ada sebagai contoh dan mempelajari atau membaca pendapat ahli yang berhubungan dengan permasalahan yang akan diteliti untuk memperoleh data yang diperlukan, serta untuk landasan teori yang akurat dan menunjang. Data sekunder juga bisa diperoleh 
baik bersumber dari buku, makalah, jurnad. Pengetesan sistem aplikasi

ataupun dari beberapa sumber internet yang berhubungan dengan tema penelitian yang dilakukan oleh peneliti.

\section{Teknik Analisis Penelitian}

Analisis penelitian yang dilakukan adalah metode analisa Research and Development dan sistem Waterfall yaitu dengan langkah-langkah (Rosa dan Shalahuddin 2015) sebagai berikut:

1. Analisa Kebutuhan

Dalam analisa kebutuhan pada sistem administrasi kursus keterampilan menjahit membutuhkan perangkat lunak (software) dan perangkat keras (hardware).

\section{Perancangan Sistem}

6. Maintenance

Merupakan tahap akhir dimana perangkat lunak yang sudah selesai dibuat, sudah mengalami beberapa perubahan atau bahkan penambahan sesuai dengan permintaan.Bagian ini juga merupakan proses terakhir yang dari pengembangan sistem laporan data administrasi yang dibuat. Pada bagian ini juga dilakukan pengkoreksian, dimana kesalahan pada sistem yang dibuat baru akan terlihat setelah sistem digunakan. Dengan melakukan pengkoreksian, maka kesalahan-kesalahan tersebut dapat diperbaiki.

Dalam perancangan sistem untuk merancang sebuah sistem aplikasi peletakan berkas rekann.

\section{HASIL DAN PEMBAHASAN}

Proses Bisnis Sistem Berjalan

beberapa diagram, seperti:
a. Diagram konteks
b. Diagram nol
c. Diagram rinci
d. Normalisasi

bentuk tidak

tidak normab

Proses Pendataan Rak

Karyawan melakukan pendataan rak untuk nantinya digunakan untuk meletakan dokumen kearsipan data rekam medik.

b. Karyawan mendata dan menyimpan data rak ke dalam file rak.

normalisasi bentuk pertama, normalisasi. Masyarakat yang ingin berobat harus melakukan bentuk kedua, dan normalisasi bentuk ketiga.

e. ERD (Entity Relationship Diagram).

3. Pengkodean daftaran terlebih dahulu kepada karyawan pendaftaran Klinik Rosmawati dengan mengisi formulir yang disediakan.

Pada tahap pengkodean ini dilakukan ke dalam file pasien.

penerjemahan dari rancangan ke dalam bahasa3. Proses Pemerikasaan Rekam Medik

pemrograman yang dapat dimengerti oleh mesi . Pasien yang sudah mengisi formulir pendaftaran (komputer). Mesin (engine) untuk sistem pasien, menyerahkan kepada karyawan Klinik informasi ini akan dibangun dengan Rosmawati dan selanjutnya akan dilakukan menggunakan bahasa pemrograman java yang pemeriksaan agar dapat diketahui hasil diagnosa akan dihubungkan dengan server database penyakit yang sedang dialami. MySQL.

b. Karyawan mendata dan menyimpan data rekam medik ke dalam file rekam medik.

\section{Pengujian Sistem}

Pada tahap pengujian sistem akan di uji setelah ${ }^{4}$ proses pengkodean selesai untuk memastikañ tidak adanya error pada sistem aplikasi dan penyesuaian pada perangkat lunak dan perangkat keras yang sudah ditentukan pada tahap analisis kebutuhan sebelum sistem aplikasi diimplementasikan kepada pengguna.

\section{Implementasi}

Pada tahap implementasi akan dibagi beberapa bagian untuk proses implementasi, sebagai berikut:

a. Pemilihan tempat dan instalasi perangkat keras dan perangkat lunak.

b. Pemilihan dan pelatihan untuk pengguna aplikasi.

\section{Proses Peletakan Rekam Medik}

Karyawan memberikan hasil rekam medik (diagnosa) kepada pasien sebagai pengetahuan tentang penyakit yang diderita.

Karyawan mendata dan menyimpan data peletakan ke dalam file rekam peletakan.

\section{Proses Laporan}

a. Pada setiap bulan, akan dibuatkan laporan data rak, laporan data pasien, laporan data rekam medik dan laporan peletakan.

Data-data pada file rak, pasien, rekam medik, dan peletakan dibuatkan laporan data, untuk diketahui oleh pimpinan Klinik Rosmawati. 
DAD Sistem Berjalan

Diagram Konteks Sistem Berjalan

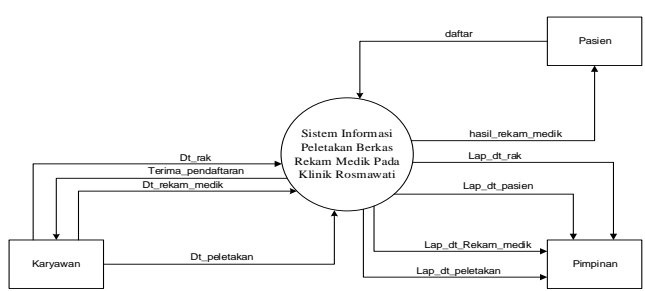

Gambar 1. Diagram Konteks Sistem Berjalan

Diagram Nol Sistem Berjalan

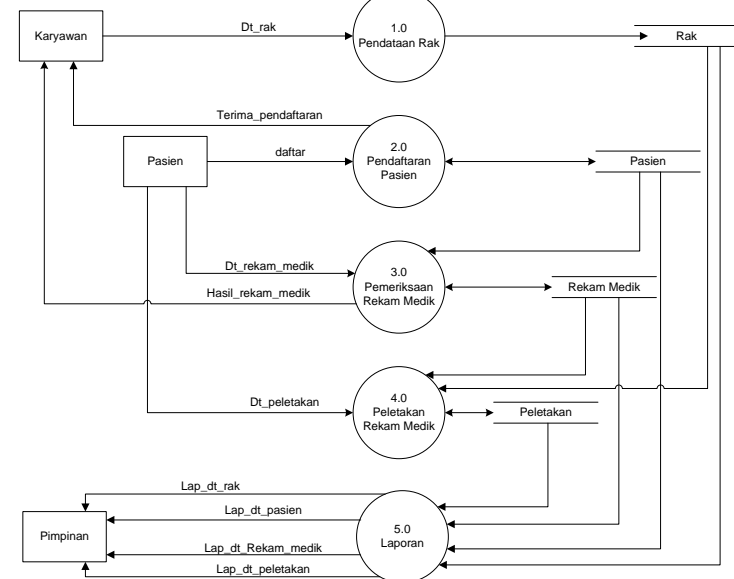

Gambar 2. Diagram Nol Sistem Berjalan

\section{Analisa Permasalahan}

Analisa adalah tahap awal dalam pengembangan sistem yang tahap fundamental yang sangat menentukan kualitas sistem informasi yang dikembangkan (Fatta dan Marco 2015). Analisa permasalahan yang dapat penulis simpulkan dari hasil penelitian yang dilakukan di Klinik Rosmawati adalah bahwa instansi ini termasuk salah satu instansi yang belum memiliki sistem informasi berbasis komputerisasi dalam pengolahan data peletakan berkas rekam medik, sehingga dirasakan masih sangat membutuhkan sistem yang mampu dan memberikan kemudahan bagi bagian-bagian yang terkait dalam sistem pengolahan data peletakan berkas rekam medik. Ada beberapa permasalahan yang dimiliki oleh pihak perusahaan salah satunya yaitu proses pembuatan laporan data pasien, rekam medik dan peletakan yang masih dilakukan pencatatan secara manual dengan menggunakan berkas sehingga menyulitkan karyawan ketika akan melakukan pencarian data ataupun pengarsipan data. Pencatatan data yang berjalan belum maksimal karena penggunaan berkas sebagai sarana pencatatan transaksi, sehingga pengerjaan laporan membutuhkan waktu yang sangat lama.

\section{Alternatif Penyelesaian Masalah}

Alternatif penyelesaian masalah yang penulis usulkan adalah dengan membuat sebuah sistem aplikasi peletakan berkas rekam medik dengan menggunakan bahasa pemrogram java dan penyimpanan data-data pada media database. Dengan adanya aplikasi ini diharapkan mampu memberikan kontribusi yang positif bagi kemajuan dalam pengolahan data-data peletakan berkas rekam medik. Proses pencarian data tidak lagi membutuhkan waktu yang lama karena datadata yang ada sudah tersimpan pada media database. Dengan usulan ini diharapkan permasalahan pada pengolahan data-data peletakan berkas rekam medik dapat tertangani dengan cepat dan akurat.

\section{DAD Sistem Diusulkan} Diagram Konteks Sistem Diusulkan

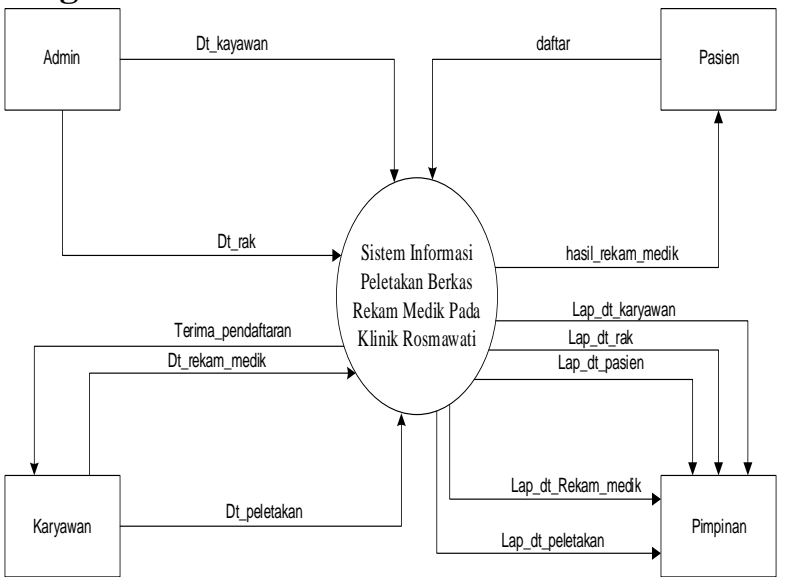

Gambar 3. Diagram Konteks Sistem Diusulkan

\section{Diagram Nol Sistem Diusulkan}

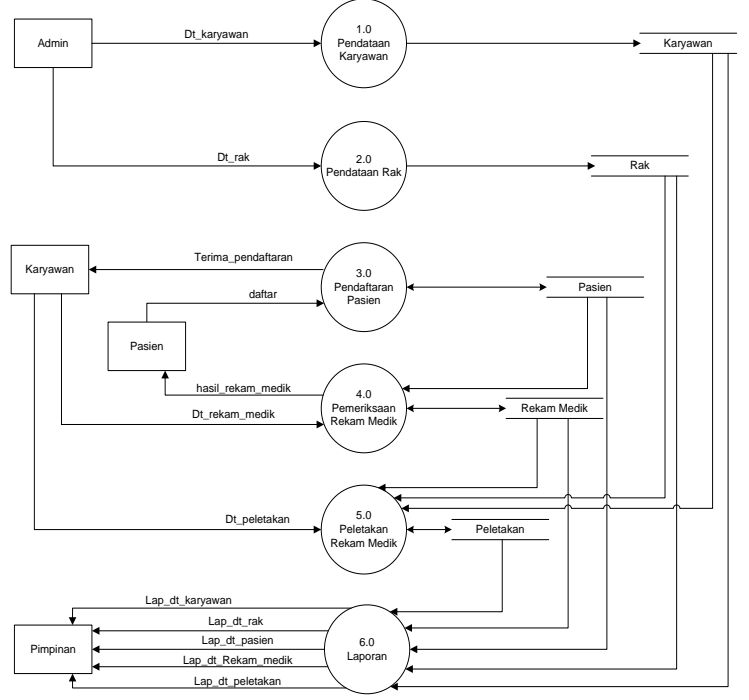

Gambar 4. Diagram Nol Sistem Diusulkan 309 | Sistem Informasi Peletakan Berkas Rekam Medik pada Klinik Rosmawati 


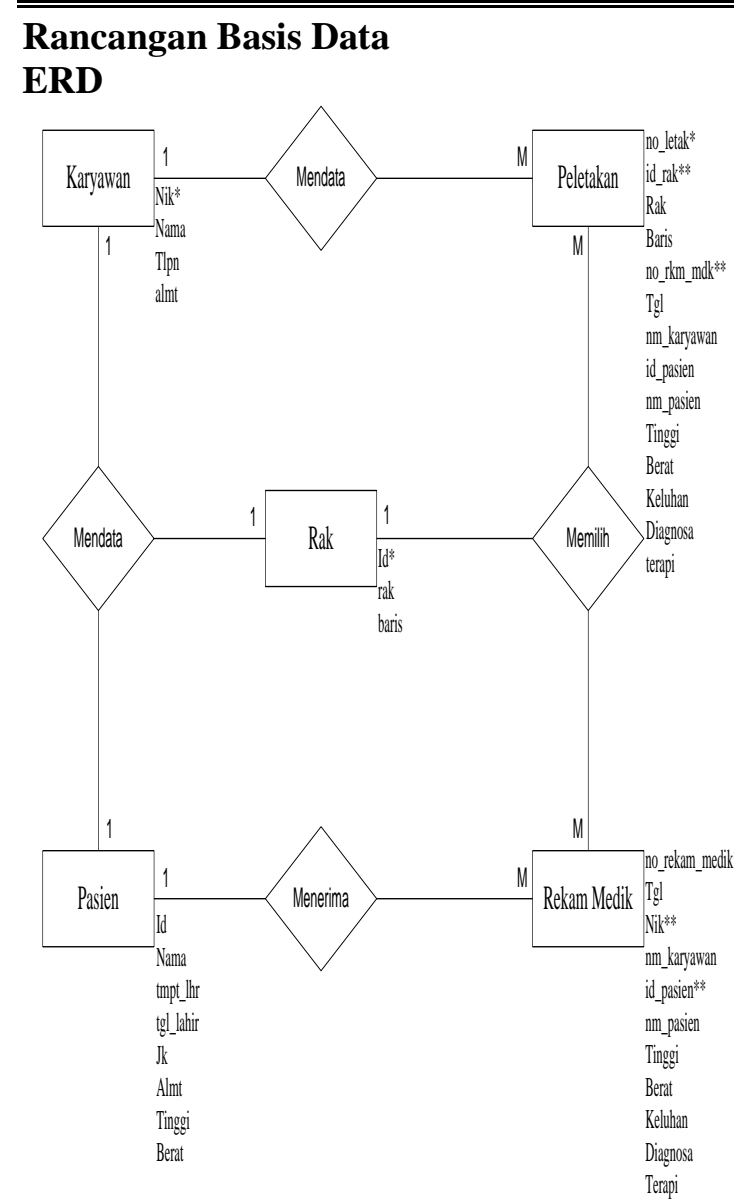

Gambar 5. ERD (Entity Relationship Diagram)

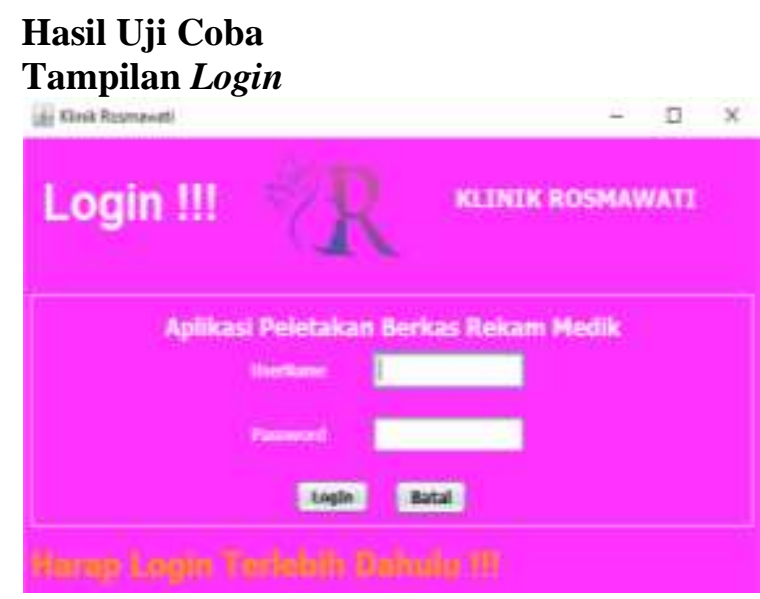

Gambar 6. Tampilan Menu Login

Tampilan form login ini muncul di awal saat pengoperasian program sistem aplikasi peletakan berkas rekam medik untuk diisi oleh admin sebagai user. Masukkan username dan password yang sesuai dengan hak akses supaya bisa mengoperasikan sistem aplikasi peletakan berkas rekam medik. Jika username dan password sesuai, maka akan masuk kepada tampilan Menu Utama.

\section{Tampilan Menu Utama}

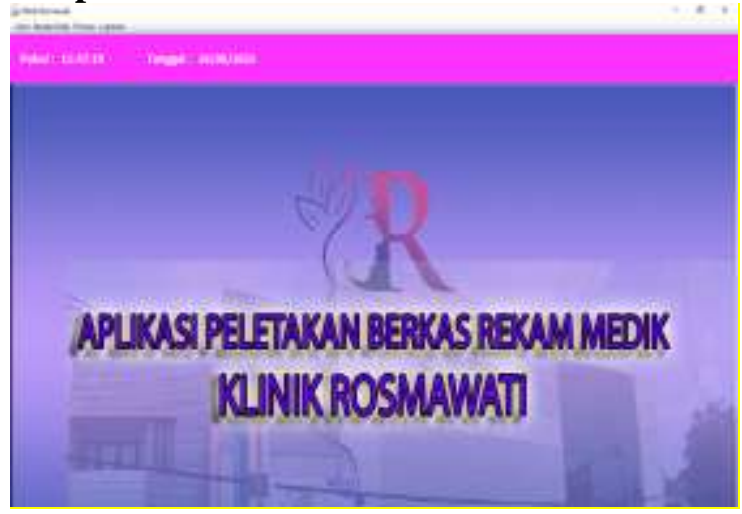

Gambar 7. Tampilan Menu Utama

Tampilan menu utama ini terdapat beberapa icon menu yang akan menampilkan form-form transaksi diantaranya adalah:

1) Admin, akan menampilkan menu semua data.

2) Data, berisikan tentang data karyawan, data rak, dan data pasien.

3) Proses, berisikan tentang, proses data rekam medik, dan proses data peletakan.

4) Laporan, berisikan tentang laporan data karyawan, rak, pasien, rekam medik, dan peletakan rekam medik.

\section{Tampilan Form Rak}

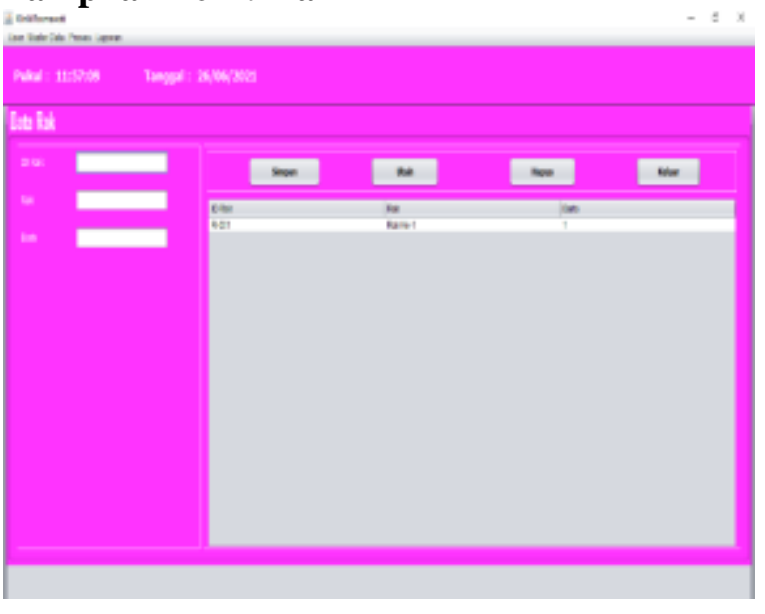

Gambar 9. Tampilan Form Rak

Tampilan form data rak ini, user dapat melakukan penambahan data rak, mengubah, dan menghapus data rak. Masukkan id rak untuk melakukan pengecekan data-data yang sudah tersimpan. Lakukan pengisian apabila akan dilakukan penambahan data dan tekan tombol (simpan) untuk menyimpan data, untuk memperbarui data tombol (ubah), dan untuk menghapus data klik tombol (hapus). Pilih tombol (keluar) apabila ingin menutup form data rak dan absen ke tampilan menu utama. 


\section{Tampilan Form Proses Peletakan}

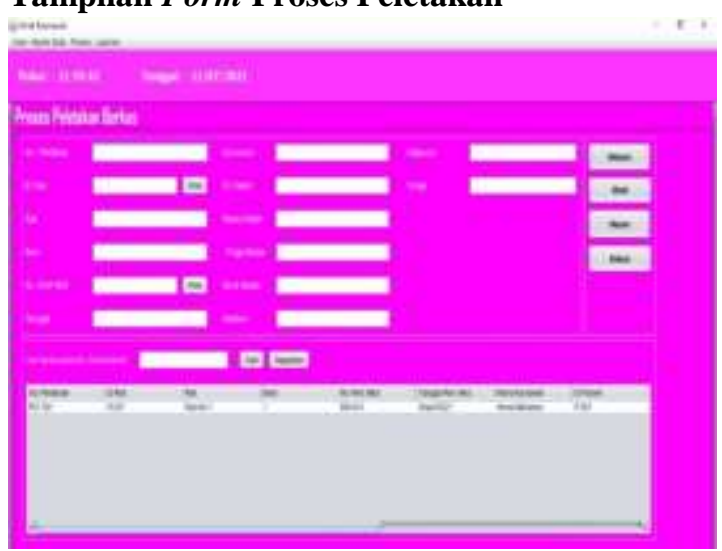

Gambar 10. Tampilan Form Peletakan

Tampilan form data peletakan ini, user dapat melakukan penambahan data peletakan, mengubah, dan menghapus data peletakan. Masukkan no peletakan untuk melakukan pengecekan data-data yang sudah tersimpan. Lakukan pengisian apabila akan dilakukan penambahan data dan tekan tombol (simpan) untuk menyimpan data, untuk memperbarui data tombol (ubah), dan untuk menghapus data klik tombol (hapus). Pilih tombol (keluar) apabila ingin menutup form data peletakan dan absen ke tampilan menu utama.

Tampilan Laporan Proses Peletakan

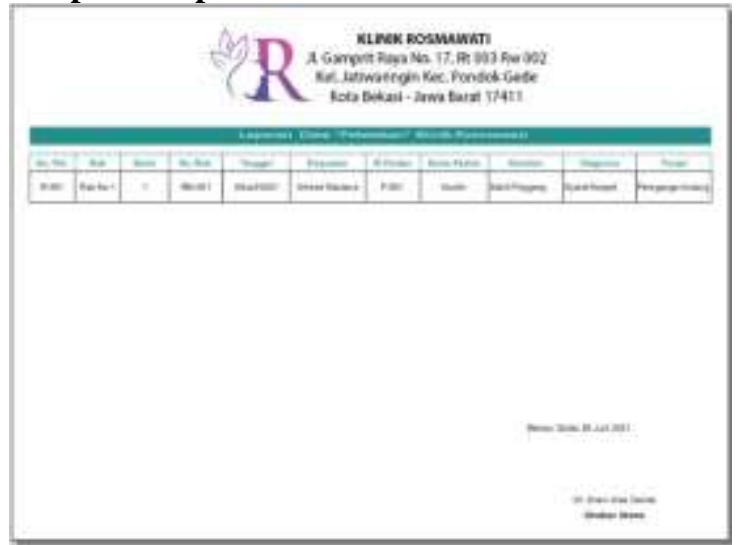

Gambar 11. Tampilan Laporan Data Peletakan

Tampilan laporan data peletakan ini berisi datadata yang ada pada tabel peletakan. Laporan ini muncul ketika user mengklik tombol laporan data peletakan pada tampilan menu utama. User bisa mencetak laporan ini dengan mengklik tombol yang bertulisan cetak yang ada di bagian bawah kiri atas.

\section{SIMPULAN DAN SARAN}

Proses sistem peletakan berkas rekam medik yang sedang berjalan pada klinik Rosmawati yaitu dengan cara menyimpan berkas rekam medik dalam rak penyimpanan bedasarkan nomor rekam medik, lalu letak berkas tersebut disimpan dalam sistem Microsoft Excel sebagai backup data.

Sistem peletakan berkas rekam medik yang dapat diterapkan pada klinik Rosmawati sehingga efektif dan efisien dalam mengolah data-data peletakan berkas rekam medik yaitu sebuah sistem berbasis java yang dapat menunjukan letak penyimpanan berkas rekam medik dan tidak perlu menggunakan sistem Microsoft Excel sebagai backup datanya karena sistem tersebut sudah terintegrasi dengan database.

Sistem peletakan berkas rekam medik yang dapat menunjang mutu pelayanan dalam meningkatkan kecepatan waktu tunggu pasien pada klinik Rosmawati adalah sebuah sistem yang dapat menyimpan letak penyimpanan dari berkas rekam medik tersebut, sehingga saat dibutuhkan user tidak perlu mencari satu persatu dalam rak, namun hanya perlu melihat sistem dan mencari menggunakan nomor dari rekam medik dalam sistem tersebut, lalu letak dari rekam medik tersebut akan muncul dan pasien tidak perlu menunggu terlalu lama karena pencarian berkas sehingga mutu pelayanan pada klinik Rosmawati dapat meningkat.

Cara mengimplementasikan sistem yang akan dibuat ke dalam bentuk bahasa pemrograman Java dengan database MySQL sehingga meminimalisir kerusakan dan kehilangan pada proses peletakan berkas rekam medik pada klinik Rosmawati dengan meyimpan semua data rekam medik, data karyawan, data identitas pasien, dan lainnya, sehingga saat terjadinya kehilangan atau kerusakan dapat segera terlihat dari laporan ireport setiap bulannya.

Sebaiknya sistem ini masih perlu diperbaharui dengan melakukan proses keterlambatan peletakan berkas rekam medik.

Penempatan arsip pada rak, sebaiknya dilakukan secara otomatis oleh sistem agar menghasilkan informasi yang akurat dan konsisten. Sistem ini diharapkan untuk dapat dikembangkan pada pengolahan data peletakan berkas rekam medik, juga dapat mengolah data keterlambatan 
peletakan berkas rekam medik, sehingga dapat Sugiyono. 2018. "Metode Penelitian Kuantitatif mencapai serta mewujudkan kinerja yang lebih baik dan maksimal.

(Research and Development/R\&D)." Bandung: Alfabeta, 458.

\section{UCAPAN TERIMAKASIH}

Dengan memanjatkan puji syukur kehadirat Allah SWT yang telah melimpahkan rahmat dan karunia-Nya kepada penulis sehingga penulis dapat menyelesaikan artikel ini tepat pada waktunya. izinkanlah penulis menyampaikan rasa hormat dan ucapan terima kasih kepada semua pihak yang dengan tulus dan ikhlas memberikan bantuan, bimbingan serta dukungan kepada penulis. Kepada ibu Lusi Ariyani dan ibu Noni Selvia terimakasih atas jasa nya sudah membantu dalam menyelesaikan dan membimbing penulis.

\section{DAFTAR PUSTAKA}

A.S. Rosa, M Shalahuddin. 2015. "Rekayasa Perangkat Lunak Terstruktur dan Berorientasi Objek." Bandung: Informatika Bandung, 65.

Barthos, Basir. 2016. "Manajemen Kearsipan Untuk Lembaga Negara, Swasta, dan Perguruan Tinggi." Jakarta: PT. Bumi Aksara, 273.

Djaman Satori, Aan Komariah. 2017. "Metode Penelitian Kualitatif (Research and Development/R\&D)." Bandung: Alfabeta, 149.

Hanif Al Fatta, R Marco. 2015. "Analisis Pengembangan dan Perancangan Sistem Informasi Akademik Smart Berbasis Cloud Computing." Yogyakarta: Telematika 8, 36.

Mohammad Nazir. 2014. "Metode Penelitian." Jakarta: Penerbit Ghalia Indonesia, 346.

Muhidin Sambas Ali, Winata Hendri. 2016. "Manajemen Kearsipan." Bandung: $C V$ Pustaka Setia, 506.

Muslikhah Dwihartanti. 2014. "Pelatihan dan Pengelolaan Arsip Bagi Guru dan Tata Kependidikan." Yogyakarta: Universitas Negeri Yogyakarta, 8.

Sugiarto, Teguh Wahyono. 2015. "Manajemen Kearsipan Modern." Yogyakarta: GAVA MEDIA, 234.

Sugiyono. 2016. "Metode Penelitian dan Pengembangan (Research and Development/R\&D)." Bandung: Alfabeta, 334. 